\title{
Cenchrus pseudotriticoides (Poaceae: Panicoideae), a resilient pyrophyte grass from Central Madagascar
}

\section{Maria S. Vorontsova ${ }^{1}$ (D)}

Summary. A new combination is made placing Pennisetum pseudotriticoides in the genus Cenchrus. This species is common and often dominant in the southern part of central Madagascar, associated with inundation and fire, and withstanding high grazing. A description, a detailed plate, a map, and list of known specimens are provided.

Key Words. Africa, Cenchrinae, grazing, fire, Paniceae, Pennisetum.

\section{Introduction}

Endemic lineages provide a window into local evolutionary history. The comparatively high endemicity of Poaceae in Madagascar indicates an ancient origin of its grass flora, while the endemic $\mathrm{C}_{4}$ lineages serve as evidence of pre-human open canopy habitats (Vorontsova et al. 2016; Hackel et al. 2018). Open grasslands of central Madagascar have likely been shaped by the same fire and grazing disturbances as the African savannas (Solofondranohatra et al. 2020) but remain designated as secondary ecosystems in the latest vegetation classification by Gautier et al. (2018). Naming, classifying and characterising the common grasses of central Madagascar is important to reconstruct ecosystem history, plan conservation, and build species knowledge to support local livelihoods.

The traditionally delimited genera Cenchrus L. and Pennisetum Rich. are both ecologically significant across the tropics, characterised by bristles surrounding and subtending each spikelet, the whole structure deciduous as a unit (Clayton \& Renvoize 1986). It has become increasingly clear that traditionally delimited Cenchrus originated from within Pennisetum, and both are now placed in the expanded genus Cenchrus in the Poaceae subfamily Panicoideae, tribe Paniceae, subtribe Cenchrinae (Chemisquy et al. 2010; Veldkamp 2014; Kellogg 2015; Soreng et al. 2017). Ten species of the united genus Cenchrus are listed for Madagascar by Bosser (1969), not including the cultivated crop pearl millet Cenchrus americanus (L.) Morrone (formerly Pennisetum glaucum (L.) R.Br.). All these species have names available under the genus Cenchrus except the sole endemic species, which is the subject of this study.
Cenchrus pseudotriticoides was originally named Pennisetum triticoides by Baker (1885). Camus (1947) published the replacement name $P$. pseudotriticoides as part of her grass inventory of the central Malagasy "prairies", followed by a more extensive description (Camus 1950) where the species was characterised as "covering hard surfaces, withstanding bush fires, but very bad fodder". The Malagasy $P$. pseudotriticoides was placed in synonymy under $P$. hohenackeri Hochst. ex Steud. by Clayton (Clayton \& Renvoize 1982) but later accepted as a distinct species by Clayton et al. (2016). It differs from $P$. hohenackeri (now known as Cenchrus hohenackeri (Hochst. ex Steud.) Morrone) by its smaller height of $50-80 \mathrm{~cm}$ (vs $60-200 \mathrm{~cm}$ ), more narrow panicles, few involucral bristles (vs numerous involucral bristles) subtending each spikelet, upper glume with absent to obscure veins (vs distinct primary and lateral veins), and a cartilaginous (vs membranous) upper lemma.

Today Cenchrus pseudotriticoides is a common roadside and village grass of south-central Madagascar. Recent ecological surveys by Solofondranohatra et al. (2020) found that its occurrence is associated with frequent fire, although it also resists grazing, becoming abundant in heavily grazed areas. The origin of the C. pseudotriticoides lineage is estimated to be around 1.8 - 2.5 Ma (Hackel et al. 2018) but is likely to be more recent since the most likely close relative C. hohenackeri was not included in the analysis. Here this species is assigned a name in the genus Cenchrus, and a summary of the data available on this species is presented. All specimens cited were seen by the author.

\footnotetext{
Accepted for publication 25 September 2020.Published online 6 April 2021

1 Comparative Plant \& Fungal Biology, Royal Botanic Gardens, Kew, Richmond, Surrey, TW9 3AE, UK. e-mail: m.vorontsova@kew.org
} 


\section{Key to close relatives of Cenchrus pseudotriticoides}

1. Plant $50-80 \mathrm{~cm}$ tall; few involucral bristles subtending each spikelet; upper glume with absent to obscure

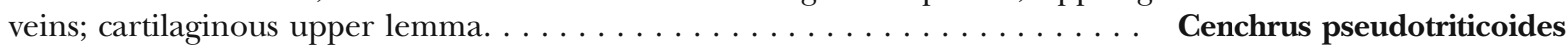

2. Plant $60-200 \mathrm{~cm}$ tall; numerous involucral bristles subtending each spikelet; upper glume with distinct primary and lateral veins; membranous upper lemma . . . . . . . . . Cenchrus hohenackeri

Cenchrus pseudotriticoides (A.Camus) Voronts. comb. nov. Type: Central Madagascar, Oct. 1881, Baron 683 (lectotype K000244663!, selected here).

http:/ /www.ipni.org/urn:lsid:ipni.org:names:77215737-1

Basionym: Pennisetum pseudotriticoides A.Camus, Rev. Int. Bot. Appl. Agric. Trop. 27: 272 (1947). Pennisetum triticoides Baker (1885: 453). nom. illegit., later homonym of Pennisetum triticoides (Poir.) Roem. \& Schult. (Roemer \& Schultes 1817: 877).

Densely caespitose perennial, firmly rooted. Culms erect; $50-80 \mathrm{~cm}$ tall. Ligule a fringe of hairs. Leafblades narrowly linear to filiform, 2-4 mm wide. Panicle spiciform, linear, $8-20 \times 0.5-0.8 \mathrm{~cm}$, the panicle branches accrescent to a central axis, the panicle axis angular, scaberulous. Spikelets subtended by an involucre of bristles. Involucral bristles easily deciduous with the fertile spikelets, $10-15$ in one whorl, 12 - $25 \mathrm{~mm}$ long, with one conspicuously longer, flexible, glabrous. Spikelets sessile, lanceolate, dorsally compressed, $7-9 \mathrm{~mm}$ long, with two florets. Lower glume minute. Upper glume $1-1.5 \mathrm{~mm}$ long, the primary vein absent or obscure, the lateral veins absent. Lower floret male or sterile. Lower lemma membranous, ovate, 7 - 9-veined, acute, with palea. Upper lemma cartilaginous, lanceolate, 7 - 9 mm long, acute. Upper palea membranous. Anthers 3. Fig. 1.

DISTRIBUTION. Central Madagascar. Map 1. SPECIMENS EXAMINED. MADAGASCAR. Antananarivo: Antananarivo, $1750 \mathrm{~m}$, 23 Jan. 1975, Croat 29117a (MO, TAN); Antananarivo, Service de l'Agriculture 410 (TAN); Tsimbazaza, Jan. 1959, Bosser 12529 (P01913209); Lac Tsimbazaza, 25 Dec. 1920, Decary 134 (P01913190); Ambohipotsy, 16 Jan. 1921, Decary 227[a] (P01913191); Nanisana, 1 Feb. 1933, Jardin Botanique de Tananarive 324-72 (P01913208); Ambatofotsy, bord de la Sisaony, 18 Dec. 1959, Peltier E Peltier 1607 (P01913197); Antananarivo, Oct. 1965, Rakotozafy 400 (TAN); Antananarivo, 18 April 1907, Rotereau s.n. (P02662478); Antananarivo, Jan. 1916, Waterlot s.n. (P01913192); Ambohimanga, Nov. 1922, Waterlot 610 ( $\mathrm{P} 01913193)$; station forestière Antsampandrano, 1750 m, 23 Jan. 1975, Croat 29099a (P02662474); Manjakatompo, 22 Dec. 1950, Benoist 643
(P01913200, P03487870); Manjakatompo, 18 Dec. 1950, Benoist 666 (P01913204); Manjakatompo, 24 May 1951, Benoist 1914 (P01913201); Akidondona village, $1571 \mathrm{~m}, 24$ April 2017, Solofondranohatra, Razanatsoa E Randriantsara SLC 828 (K, TAN); Malama maina, Ambatolampy, 1620 m, 25 April 2017, Solofondranohatra, Razanatsoa E Randriantsara SLC 837 (K, TAN); Mahazoarivo village, near Ihazolava, 1568 m, 26 April 2017, Solofondranohatra, Razanatsoa E Randriantsara SLC 858 (K, TAN); Malama maina, near Ilampy hotel, 1608 m, 26 April 2017, Solofondranohatra, Razanatsoa E Randriantsara SLC 892 (K, TAN); Andakana, 1251 m, 8 May 2017, Solofondranohatra E Razanatsoa SLC 1032 (K, TAN); Andakana, 1251 m, 8 May 2017, Solofondranohatra $\mathcal{E}$ Razanatsoa SLC 1034 (K, TAN); Antsirabe centre, 1600 m, Jan. 1913, Perrier de la Bâthie 10766 (P01913186); pentes du Tritriva, 1700 - 1800 m, 16 Nov. 1912, Viguier $\mathcal{E}$ Humbert 1342 (P01913205, P02662481); Faratsiho, 3 July 1964, Tateoka 3556 (TAN); Merinavaratra, 28 March 1938, Jardin Botanique de Tananarive 3665 (P01913206, P01913207). Fianarantsoa: Fianarantsoa Rural, $1365 \mathrm{~m}, 25$ Jan. 1975, Croat 29575 (MO, TAN); Fianarantsoa Rural, 1365 m, 25 Jan. 1975, Croat 29626 (MO, TAN); Fianarantsoa Rural, 1600 m, 28 Jan. 1975, Croat 30043 (MO, TAN); route Fianarantsoa - Antsirabe, 21 Jan. 1967, Delhaye 103 (P02662465); Fianarantsoa, prairies, March 1912, Perrier de la Bâthie 10875 (P01913187, P01913188). Province not known: s. coll. 10686 (P01913189); s. coll. 10688 (P01913195, P01913198); Baron 3204 (P01913202); June 1889, Baron 3254 (P01913203); Central Madagascar, Dec. 1883, Baron 3294 (lectoparatype, K000244662); 20 Jan. 1950, Decary 690 (P01913196); Central Madagascar, August 1880, Parker s.n. (lectoparatype, K000244626); Scott-Elliot 1730 (P01913199); Scott-Elliot s.n. (K000244664); 25 June 1964, Tateoka 3502 (TAN).

HABITAT. Sandy and silty river banks, open grassland, grazing lawns, trampled and heavily grazed locations, roadsides, $1000-2000 \mathrm{~m}$.

CONSERvation Status. Assessed here as Least Concern (LC) due to its widespread occurrence (IUCN 2001): extent of occurrence appears to be in excess of $20,000 \mathrm{~km}^{2}$ and area of occupancy is above $2,000 \mathrm{~km}^{2}$. VERNACULAR NAME. Horompotsy, Tohiambazaha (Bosser 1969). 


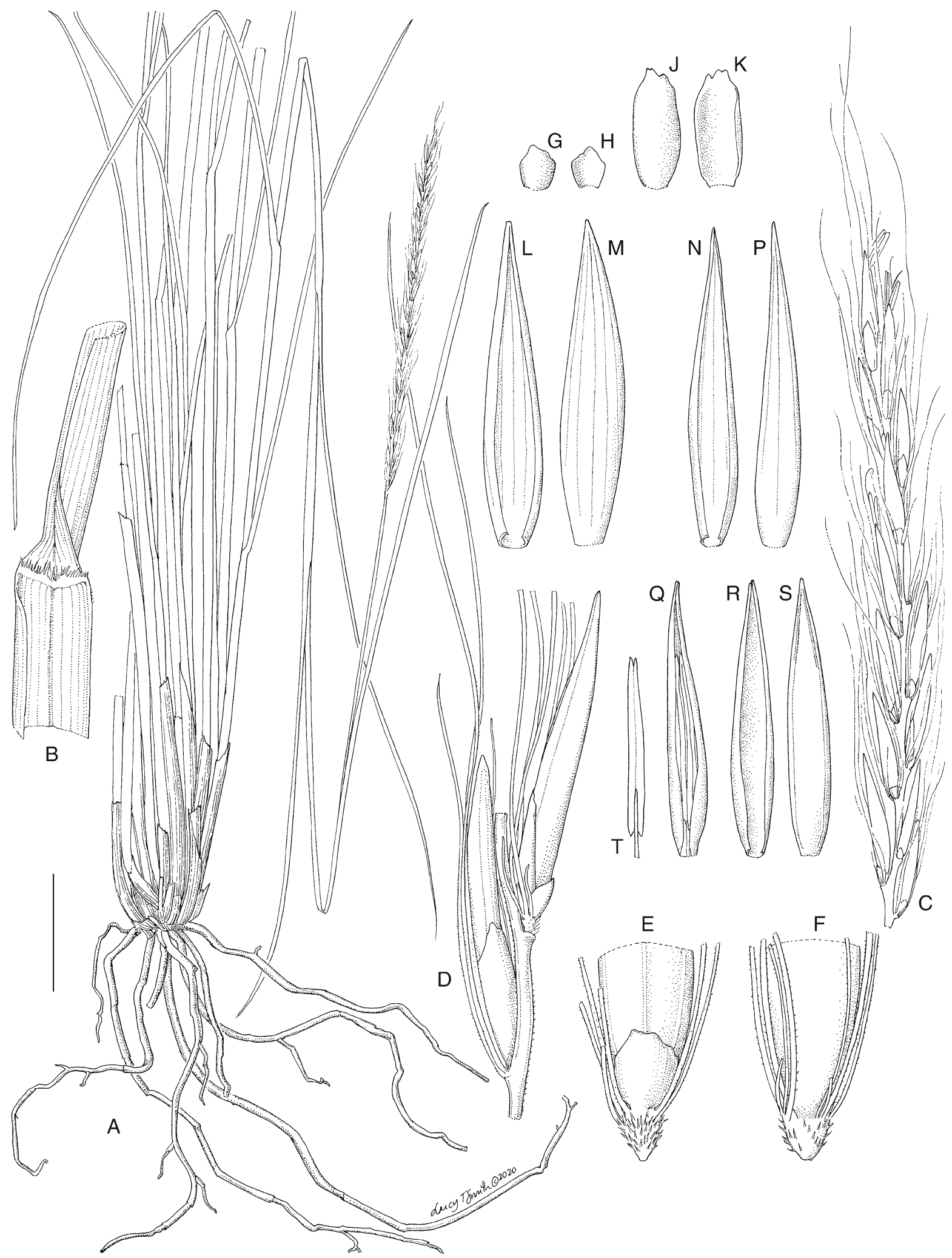

Fig. 1. Cenchrus pseudotriticoides. A habit, part of broader dense tussock removed; B ligule; C panicle; D panicle branch with two spikelets subtended by involucres of bristles; $\mathrm{E}$ basal part of spikelet showing callus and upper glume; $\mathrm{F}$ basal part of spikelet showing callus (lower glume removed); G lower glume, dorsal view; H lower glume, ventral view; J upper glume, dorsal view; K upper glume, ventral view; L lower lemma, ventral view; M lower lemma, dorsal view; N lower palea, ventral view; P lower palea, dorsal view; Q upper floret with palea removed; R upper lemma, ventral view; S upper palea, dorsal view; T stamen. Scale bar: $\mathbf{A}=$ $2 \mathrm{~cm} ; \mathrm{B}, \mathrm{D}, \mathrm{G}-\mathrm{T}=3.5 \mathrm{~mm} ; \mathrm{C}=5 \mathrm{~mm} ; \mathrm{E}, \mathrm{F}=3 \mathrm{~mm}$. Drawn from Baron 683. DRAWI BY LUCY T. SMITH.> 


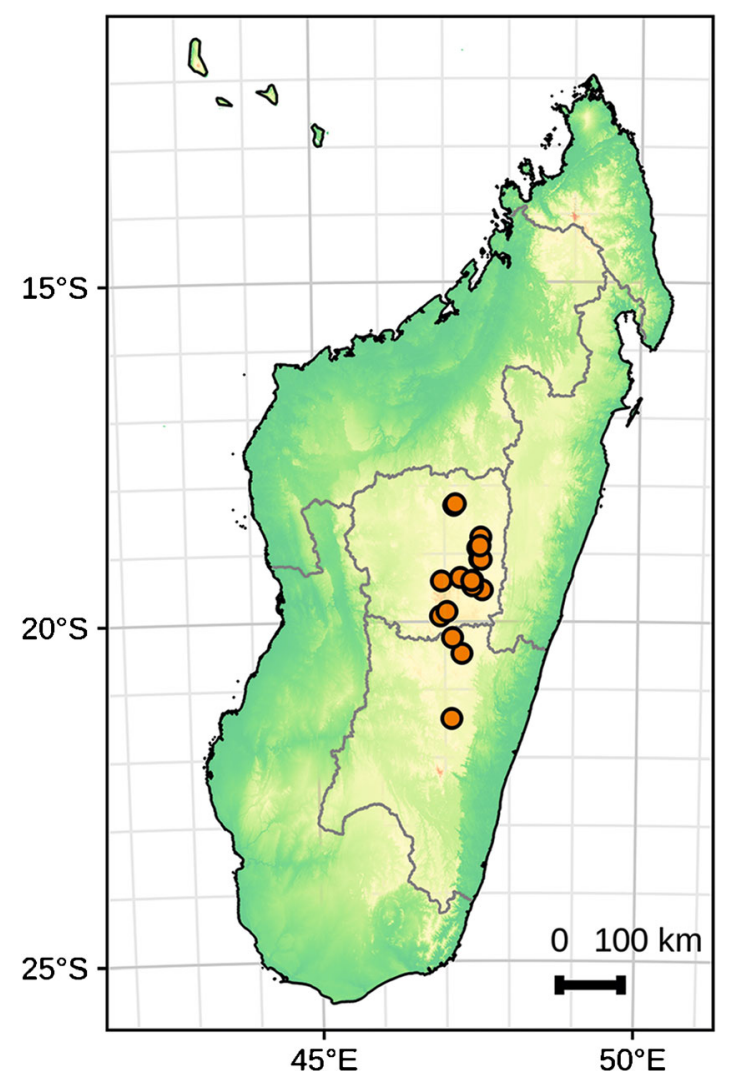

Map 1. Distribution of Cenchrus pseudotriticoides in Madagascar. Grey lines indicate major provinces. Green to yellow shading indicates elevation. DRAWN BY SARAH Z. FICINSKI.

USES. Effective for preventing soil erosion and limiting runoff due to its powerful roots. Poor fodder. (Bosser 1969).

NOTES. Dominant on some sandy alluvia and sandy ridges on the banks of rivers, can withstand temporary submergence (Bosser 1969). Covers vast areas (fide Perrier de la Bâthie 10875). The lectotype is selected due to its superior quality material and annotations on the sheet.

The type material of Panicum triticoides Poir. (Poiret 1816: 274) has still not been located following the search last conducted by Veldkamp (2014) and thus the application of Pennisetum triticoides (Poir.) Roem. \& Schult. (Roemer \& Schultes 1817: 877) and Cenchrus triticoides (Poir.) Veldkamp (2014: 71) remains unclear.

\section{Acknowledgements}

Thank you to everyone at the Kew Madagascar Conservation Centre for sharing knowledge and for support with field work. Thank you to the curators of the $\mathrm{P}$ herbarium for making specimens available, especially online. Thank you to Lucy T. Smith and Sarah Z. Ficinski for the beautiful illustrations.
Open Access This article is licensed under a Creative Commons Attribution 4.0 International License, which permits use, sharing, adaptation, distribution and reproduction in any medium or format, as long as you give appropriate credit to the original author(s) and the source, provide a link to the Creative Commons licence, and indicate if changes were made. The images or other third party material in this article are included in the article's Creative Commons licence, unless indicated otherwise in a credit line to the material. If material is not included in the article's Creative Commons licence and your intended use is not permitted by statutory regulation or exceeds the permitted use, you will need to obtain permission directly from the copyright holder. To view a copy of this licence, visit http://creativecommons.org/ licenses/by/4.0/.

\section{References}

Baker, J. G. (1885). Further contributions to the Flora of Madagascar. Second and Final Part. J. Linn. Soc., Bot. 21: 407 - 455.

Bosser, J. M. (1969). Graminées des pâturages et des cultures à Madagascar. ORSTOM, Paris.

Camus, A. (1947). Sur les Graminées des prairies de Madagascar. Rev. Int. Bot. Appl. Agric. Trop. 27, bull. no. 297-298: 271 - 281. https://doi.org/10.3406/ jatba.1947.2060

(1950). Sur deux graminées de Madagascar. Bull. Mus. Natl. Hist. Nat. sér. 2, 22: 296 - 297.

Chemisquy, M. A., Giussani, L. M., Scataglini, M. A., Kellogg, E. A. \& Morrone, O. (2010). Phylogenetic studies favour the unification of Pennisetum, Cenchrus and Odontelytrum (Poaceae): a combined nuclear, plastid and morphological analysis, and nomenclatural combinations in Cenchrus. Ann. Bot. 106: 107 - 130 .

Clayton, W. D. \& Renvoize, S. A. (1982). Flora of tropical East Africa. Gramineae. Part 3. A. A. Balkema, Rotterdam. \& don. (1986). Genera Graminum. HMSO, Lon-

, Vorontsova, M. S., Harman, K. T. \& Williamson, H. (2016). GrassBase - The Online World Grass Flora. The Board of Trustees, Royal Botanic Gardens, Kew. http://www.kew.org/data/grasses-db/ index.htm Accessed 17 Feb. 2016.

Gautier, L., Tahinarivony, J. A., Ranirison, P. \& Wohlhauser, S. (2018). Vegetation. In: Les aires protégées terrestres de Madagascar: Leur histoire, description et biote / The terrestrial protected areas of Madagascar: Their history, description, and biota, eds S. M. Goodman, M. J. Raherilalao \& S. Wohlhauser, chapter 7, pp. 207 - 242. Association Vahatra, Antananarivo. 
Hackel, J., Vorontsova, M. S., Nanjarisoa, O. P., Hall, R. C., Razanatsoa, J., Malakasi, P. \& Besnard, G. (2018). Grass diversification in Madagascar: In situ radiation of two large C3 shade clades and support for a Miocene to Pliocene origin of C4 grassy biomes. J. Biogeogr. 45: 750 - 761. https://doi.org/ 10.1111/jbi.13147

IUCN (2001). IUCN Red List Categories and Criteria: Version 3.1. IUCN Species Survival Commission. IUCN, Gland \& Cambridge.

Kellogg, E. A. (2015). Flowering plants. Monocots: Poaceae. In: The families and genera of vascular plants, Vol. 13, ed. K. Kubitzki. Springer, Heidelberg.

Poiret, J. L. M. (1816). Encyclopedie Methodique. Botanique. Supplement 4. Panckoucke, Paris; Plomteaux, Liège.

Roemer, J. J. \& Schultes, J. A. (1817). Systema vegetabilium: secundum classes, ordines, genera, species. Ed. 15 bis, Vol. 2. Stuttgardtiae.

Solofondranohatra, C. L., Vorontsova, M. S., Hempson, G. P., Hackel, J., Cable, S., Jeannoda, V. \& Lehmann, C. E. R. (2020). Fire and grazing determined grasslands of central Madagascar rep- resent ancient assemblages. Proc. R. Soc. B 287 (1927).

Soreng, R. J., Peterson, P. M., Romaschenko, K., Davidse, G., Teisher, J. K., Clark, L. G., Barberá, P., Gillespie, L. J. \& Zuloaga, F. O. (2017). A worldwide phylogenetic classification of the Poaceae (Gramineae) II: An update and a comparison of two 2015 classifications. J. Syst. Evol. 55: $259-290$.

Veldkamp, J. F. (2014). A revision of Cenchrus incl. Pennisetum (Gramineae) in Malesia with some general nomenclatural notes. Blumea 59: 59 - 75.

Vorontsova, M. S., Besnard, G., Forest, F., Malakasi, P., Moat, J., Clayton, W. D., Ficinski, S., Savva, G. M., Nanjarisoa, O. P., Razanatsoa, J., Randriatsara, F. O, Kimeu, J. M., Luke, W. R. Q., Kayombo, C. \& Linder, H. P. (2016). Madagascar's grasses and grasslands: anthropogenic or natural? Proc. R. Soc. $B$ 283(1823). DOI: https://doi.org/10.1098/ rspb.2015.2262.

\section{Publisher's Note}

Springer Nature remains neutral with regard to jurisdictional claims in published maps and institutional affiliations. 